\title{
Brain tissue oxidative damage as a possible mechanism for the deleterious effect of a chronic high dose of estradiol on learning and memory in ovariectomized rats
}

\author{
Dano oxidativo ao tecido cerebral como possível mecanismo de efeito deletério da alta \\ dose crônica de estradiol no aprendizado e memória de ratas ooforectomizadas
}

Fatimeh Khodabandehloo', Mahmoud Hosseini², Ziba Rajaei ${ }^{3}$, Mohammad Soukhtanloo 4 , Esmaeil Farrokhi², Mohsen Rezaeipour²

\begin{abstract}
In addition to antioxidative effects, estrogens also exert pro-oxidative actions. The effect of chronic administration of a high dose of estradiol valerate on Morris water maze tasks and brain tissues oxidative damage was investigated. The Sham-Est and OVX-Est groups were treated with estradiol valerate $(4 \mathrm{mg} / \mathrm{kg}$ ) for 12 weeks. Escape latency and traveled path in the Sham-Est and OVX-Est groups were significantly higher than in the Sham and OVX groups ( $p<0.01$ and $p<0.001)$. In the probe trial, the animals of the Sham-Est and OVX-Est groups spent lower time in $Q_{1}$ compared to Sham and OVX groups ( $p<0.05$ and $\left.p<0.001\right)$. In Sham-Est and OVX-Est groups, the brain tissue total thiol concentration was significantly lower, and malondialdehyde (MDA) concentrations were higher than in the Sham and OVX groups ( $<<0.05$ and $p<0.001)$. It is concluded that administration of high exogenous levels of estradiol impairs performance and enhances oxidative stress.
\end{abstract}

Key words: learning, memory, ovariectomy, estradiol, morris water maze, oxidative stress.

\section{RESUMO}

Além dos efeitos antioxidantes, os estrógenos também têm ação pró-oxidativa. Foi investigado o efeito da administração crônica de alta dose de valereato de estradiol no desempenho do labirinto aquático de Morris e o dano oxidativo ao tecido cerebral. Os grupos Sham-Est e OVX-Est foram tratados com valereato de estradiol ( $4 \mathrm{mg} / \mathrm{kg}$ ) por 12 semanas. 0 tempo de latência para escapada e o caminho percorrido foram significativamente maiores nos grupos Sham-Est e OVX-Est em relação aos grupos Sham e OVX ( $p<0,01$ e p<0,001). No estudo probe, os animais dos grupos Sham-Est e OVX-Est levaram menos tempo no $Q_{1}$ em comparação aos grupos Shame OVX ( $p<0,05$ e $p<0,001$ ). Nos grupos Sham-Est e OVX-Est, a concentração total de tiol foi significativamente menor, enquanto a concentração de malondialdehydo (MDA) for maior do que aquela dos grupos Sham e OVX ( $p<0,05$ e p<0,001). Concluiu-se que a administração de altas doses de estradiol exógeno compromete o desempenho e aumenta o estresse oxidativo naqueles animais.

Palavras-Chave: aprendizado, memória, ovariectomia, estradiol, Labirinto Aquático de Morris, estresse oxidativo.

Ovarian hormones affect a wide variety of nervous system functions especially the cognitive abilities, learning and memory ${ }^{1}$. It has been suggested that estrogen may prevent cognitive impairments due to aging². Increasing in the risk of Alzheimer's disease due to estrogen deficiency has been reported ${ }^{3}$. It was also found that estrogens have enhancing action on memory tasks ${ }^{4}$. Controversially, some researchers observed no effects or even a negative effect of estrogens on the learning and memory functions ${ }^{5,6}$. It seems that these differential effects are related to the used dose and serum estradiol level ${ }^{7}$. Low levels of exogenous estradiol improves learning and memory tasks ${ }^{7}$, whereas administration of high

1Department of Physiology, School of Medicine, AJA University of Medical Sciences, Tehran, Iran;

${ }^{2}$ Neurocognitive Research Center and Department of Physiology, School of Medicine, Mashhad University of Medical Sciences, Iran;

${ }^{3}$ Department of Physiology, School of Medicine, Isfahan University of Medical Sciences, Isfahan, Iran;

4Department of Biochemistry, School of Medicine, Mashhad University of Medical Sciences, Iran.

Correspondence: Mahmoud Hosseini; Department of Physiology, School of Medicine, Mashhad University of Medical Sciences; Mashhad-Iran;

E-mail: hosseinim@MUMS.ac.ir

Conflict of interest: There is no conflict of interest to declare.

Received 18 September 2012; Received in final form 05 December 2012; Accepted 12 December 2012. 
exogenous pharmacological or physiological levels of estradiol impair learning and memory performances ${ }^{7,8}$. The results of our previous studies showed that treatment of ovariectomized rats by $2 \mathrm{mg} / \mathrm{kg} /$ week of estradiol valerate improved spatial learning and memory while in sham operated rats the effect of estradiol was negative ${ }^{4}$.

The central nervous system (CNS) tissues contain a high level of membranes and fatty acids. It has also been shown that the susceptibility of membrane lipid constituents in the CNS to oxidative injury is very high ${ }^{9}$. It has also been well documented that oxidative damage plays an important role in the pathogenesis of various CNS disorders and neurobehavioral impairments ${ }^{9}$. There is good evidence that oxidative stress and reactive oxygen species contribute in the learning and memory impairments. Stress-induced lipid peroxidation affects learning and memory performances in the rat conversely, and antioxidants have been shown to prevent memory impairments in various experimental models ${ }^{9}$.

Interestingly, antioxidant actions of estrogens have been long recognized in a variety of in vitro and in vivo models ${ }^{10}$. Estrogen has been found to protect against a wide range of toxic insults including free radical generators and excitotoxicity $^{11}$. The beneficial effects of estrogen in the CNS, especially, on learning and memory have been frequently attributed to its protective properties against oxidative damage ${ }^{10}$.

The aim of present study was to evaluate the effect chronic administration of a high dose of estradiol valerate on spatial learning and memory tasks and brain tissues oxidative damage in ovariectomized rats.

\section{METHODS}

\section{Animals and drugs}

Thirty two female Wistar rats with 16 weeks old and weighing $240 \pm 10 \mathrm{~g}$ were used. The animals were housed in 4-5 per standard cages, at room temperature $\left(22 \pm 2^{\circ} \mathrm{C}\right)$, on a $12 \mathrm{~h}$ light/dark cycle. Food and water were available ad libitum properly. Animal handling and all related procedures were approved by the Mashhad Medical University Committee on Animal Research. The animals were divided into four groups: (1) Sham, (2) ovariectomized (OVX), (3) Sham-estradiol (Sham-Est) and (4) ovariectomized-estradiol (OVX-Est). The animals in the Sham-Est and OVXEst groups were treated by weekly injections of estradiol valerate ( $4 \mathrm{mg} / \mathrm{kg}$; S.c.) for 12 weeks. The animals of Sham and OVX groups received $1 \mathrm{~mL} / \mathrm{kg}$ of saline instead of estradiol. All animals were tested in Morris water maze. Ketamin was purchased from Alfasan Company (Holand). $\beta$ - estradiol was kindly provided by Iran - Hormone Pharm (Tehran, Iran). Other chemicals which were used for malondialdehyde (MDA) and total thiol (SH) concentrations were purchased from Merck Company.

\section{Surgery}

Before surgery, the rats were permitted 15 days for acclimatization to the animal house. The animals were ovariectomized under ketamine anesthesia (150 mg/kg, i.p.). Anesthesia was confirmed by reduced respiratory rate and no response to gentle pinching of foot pad. Abdominal incision was made through the skin of the flank of the rats and ovaries and ovarian fats were removed. Ovaries were isolated by ligation of the most proximal portion of the oviduct before removal. The same procedure was performed on the Sham rats, except that the wound was closed without removing the ovaries.

\section{Apparatus}

The Morris water maze was a black circular pool with a diameter of $136 \mathrm{~cm}$ and a height of $60 \mathrm{~cm}$, filled with $24 \pm 1^{\circ} \mathrm{C}$ water to a depth of $30 \mathrm{~cm}$. The maze was divided geographically into four equal quadrants and release points were designed at each quadrant as North (N), East (E), South (S) and West (W). A hidden circular platform (10 cm in diameter), made of plexiglass, was located in the center of the southeast quadrant, submerged $1.5 \mathrm{~cm}$ beneath the surface of the water. Fixed, outside of the maze, visual cues were present at various locations around the maze (i.e. computer, hardwares and posters). A tracking system was used to measure the escape latency and traveled path.

\section{Behavioral assessment}

The Morris water maze task for testing spatial memory was assessed in a water tank as described previously. The animals received a block of four trials during five daily sessions. During five days, the platform, situated in the center of the southeast quadrant, was submerged $1.5 \mathrm{~cm}$ below the surface of water and therefore invisible. The platform position remained stable during five days. A trial was started by placing a rat into the pool, facing the wall of the tank. Each of four starting positions (N, E, S, W) was used once in a series of four trials and their order was randomized. Each trial was terminated as soon as the rat had climbed onto the platform or when 60 seconds had elapsed. The animal was allowed to stay on the platform for 15 seconds. Then, it was taken from the platform and the next trial was started after 20 seconds. The rats which did not find the platform within $60 \mathrm{~s}$ were put on the platform by the experimenter and were allowed to stay there for 15 seconds. After completion of the $4^{\text {th }}$ trial, the animals were kept warm for an hour, and then returned to their home cage. The escape latency and traveled path were calculated by a computer. In the retention phase, the platform was removed (in sixth day) and a 60 seconds probe trial was conducted to examine how well the rats had learned the exact location of the platform. The animals were allowed to swim for $60 \mathrm{~s}$. The time spent in the target quadrant (Q1) and non target quadrants (Q2-Q4), as well the 
traveled path, were compared between groups. All tests were conducted between $16 \mathrm{~h}$ and $18 \mathrm{~h}$ o'clock.

\section{Biochemical assessment}

Finally, the animals were sacrificed and the brain tissues (cortical tissues) were removed, weighed and submitted to determination of $\mathrm{SH}$ groups and MDA concentrations. Total SH groups were measured using DTNB (2, 2'-dinitro5, 5-dithiodibenzoic acid) as the reagent. This reagent reacts with the SH groups to produce a yellow colored complex which has a peak absorbance at $412 \mathrm{~nm}$. Briefly, $1 \mathrm{~mL}$ Tris-EDTA buffer ( $\mathrm{pH}=8.6$ ) was added to $50 \mu \mathrm{L}$ brain homogenate in $1 \mathrm{~mL}$ cuvettes, and sample absorbance was read at $412 \mathrm{~nm}$ against Tris-EDTA buffer alone (A1). Then, $20 \mu \mathrm{L}$ DTNB reagents (10 $\mathrm{mM}$ in methanol) were added to the mixture and, after $15 \mathrm{~min}$ (stored in laboratory temperature), the sample absorbance was read again (A2). The absorbance of DTNB reagent was also read as a blank (B). Total thiol concentration $(\mathrm{mM})$ was calculated from the following equation.

Total thiol concentration $(\mathrm{mM})=(\mathrm{A} 2-\mathrm{A} 1-\mathrm{B}) \times 1.07 / 0.05 \times 13.6$

MDA levels, as an index of lipid peroxidation, were measured. MDA reacts with thiobarbituric acid (TBA) as a thiobarbituric acid reactive substance (TBARS) to produce a red colored complex which has peak absorbance at $535 \mathrm{~nm}$. Two $\mathrm{mL}$ from reagent of TBA/trichlorooacetic acid (TCA)/hydrochloric acid (HCL) was added to $1 \mathrm{~mL}$ of homogenate, and the solution was heated in a water bath for 40 minutes. After cooling, the whole solutions were centrifuged within $1000 \mathrm{~g}$ for 10 minutes.

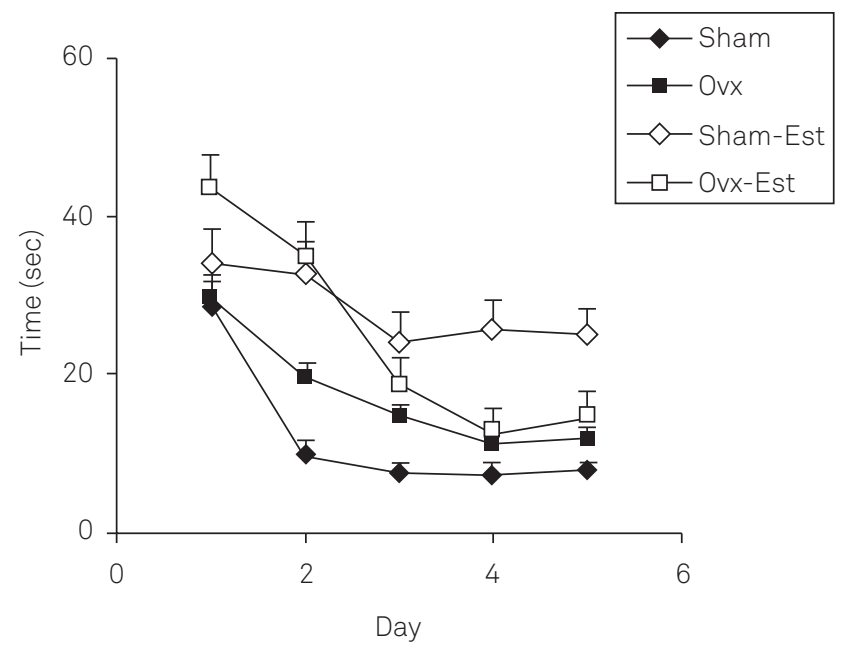

OVX: ovariectomized; Sham-Est: Sham-estradiol; OVX-Est: ovariectomizedestradiol; SEM: standard error median. Data are presented as mean \pm SEM ( $n=8$ in each group). The animals of Sham-Est and OVX-Est groups were treated by $4 \mathrm{mg} / \mathrm{kg}$ estradiol valerate for 12 weeks. The Sham and OVX groups were injected by saline instead of estradiol. The latency time was significantly higher in OVX group compared to Sham group ( $p<0.05)$. In ShamEst and OVX-Est groups, the time latency was significantly higher than Sham and OVX groups respectively $(p<0.001$ and $p<0.01)$.

Fig 1. Comparison of time latency (sec) to reach the platform between Sham, OVX, Sham-Est and OVX-Est groups.
The absorbance was measured at $535 \mathrm{~nm}$. The MDA concentration was calculated as follows: $\mathrm{C}(\mathrm{m})=$ Absorbance $/\left(1.56 \times 10^{5}\right)$.

\section{Statistical analysis}

All data were expressed as means \pm standard error median (SEM). The data of different groups during five days were compared using repeated measures ANOVA test with Tukeys' post hoc between groups. The data obtained from probe trial was compared using one-way ANOVA and post hoc test. Data for MDA and total SH groups were evaluated by oneway ANOVA and post hoc test. Differences were considered statistically significant when $\mathrm{p}<0.05$.

\section{RESULTS}

Escape latency and traveled path in the OVX group were significantly higher than in the Sham group $(p<0.05$ and $\mathrm{p}<0.001$, respectively) (Figs 1 and 2). The animals of the ShamEst group had significantly higher time and path length to reach the platform compared to Sham group (both $\mathrm{p}<0.001$ ) (Figs 1 and 2). In the OVX-Est group, escape latency and traveled path were also significantly higher than in the OVX group $(\mathrm{p}<0.01$ and $\mathrm{p}<0.001$, respectively) (Figs 1 and 2). There were no differences between the Sham-Est and OVX-Est groups in escape latency and path length (Figs 1 and 2).

In the probe trial, there were no significant differences in the time spent in target quadrant (Q1) between Sham and OVX groups (Fig 3). However, the animals of OVX group spent more time in non-target quadrant (Q4) in

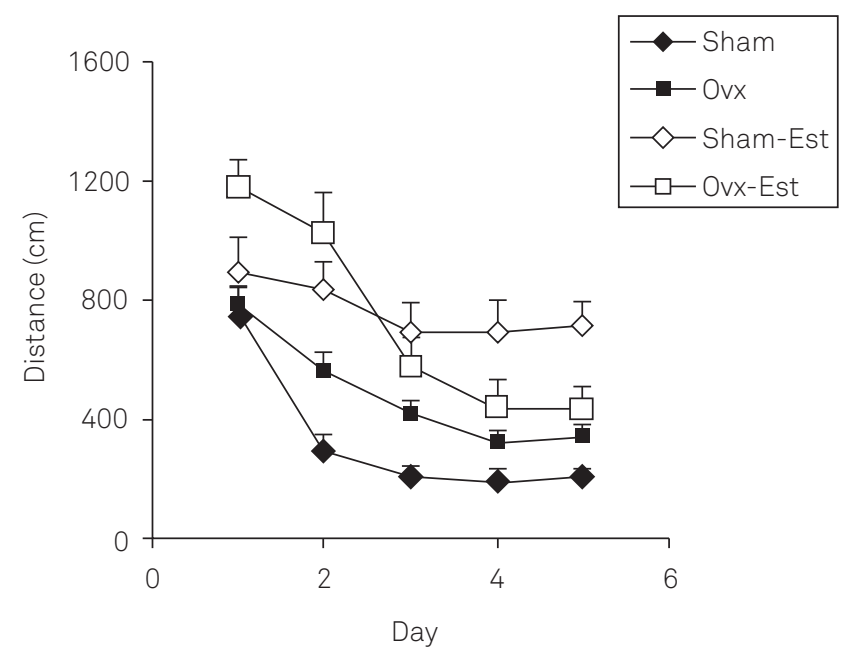

OVX: ovariectomized; Sham-Est: Sham-estradiol; OVX-Est: ovariectomizedestradiol; SEM: standard error median. Data are presented as mean \pm SEM ( $n=8$ in each group). The animals of Sham-Est and OVX-Est groups were treated by $4 \mathrm{mg} / \mathrm{kg}$ estradiol valerate for 12 weeks. The Sham and OVX groups were injected by saline instead of estradiol. The length of swimming path was significantly higher in OVX group compared to group 1 ( $p<0.001)$. In Sham-Est and OVX-Est groups, the length of swimming path was significantly higher than Sham and OVX groups respectively $(p<0.001)$.

Fig 2. Comparison of the length of swimming path $(\mathrm{cm})$ between Sham, OVX, Sham-Est and OVX-Est groups. 




OVX: ovariectomized; Sham-Est: Sham-estradiol; OVX-Est: ovariectomizedestradiol; SEM: standard error median. Data are shown as mean \pm SEM of seven animals per group. The platform was removed, and the time spent in the target quadrant (Q1) and non target quadrants (Q2-Q4) was compared between the groups. ${ }^{*} p<0.05,{ }^{* *} p<0.01$ compared to Sham group, ${ }^{++} p<0.001$ compared to OVX group.

Fig 3. The results of the time (sec) spent in each quadrant during the probe trial on day 6 ( $24 \mathrm{~h}$ after the last secession of learning).

comparison with Sham - operated rats $(\mathrm{p}<0.01)$ (Fig 3). The animals of the Sham-Est group spent lower time in Q1 compared to Sham group $(\mathrm{p}<0.05)$ (Fig 3$)$. The time spent in Q1 by the animals of OVX-Est group was significantly lower than of OVX group $(\mathrm{p}<0.01)$ (Fig 3). The animals of Sham-Est group spent more time in non-target quadrants (Q3 and Q4) when compared with Sham group (both $\mathrm{p}<0.05$ ) (Fig 3). The animals of OVX-Est group also spent more time in non-target quadrants (Q3) in comparison with OVX group ( $\mathrm{p}<0.001)$ (Fig 3). Fig 4 showed the animals of OVX group swam more distance in non target quadrant (Q4) in comparison with Sham group $(\mathrm{p}<0.01)$. The traveled path length by the animals of OVX-Est group in target quadrant was lower than OVX group $(\mathrm{p}<0.001)$ (Fig 4). However, the animals of OVX-Est group traveled longer distance in non target quadrant(Q3) compared to OVX group $(p<0.001)$. The animals of Sham-Est group traveled longer distances in non-target quadrants (Q3 and Q4) in comparison Sham group ( $\mathrm{p}<0.01$ ) (Fig 4).

The total thiol concentration in cortical tissues of ovariectomized rats were significantly lower than Sham animals $(p<0.01)$. In both OVX-Est and Sham-Est groups, the total thiol concentration were significantly lower than OVX and Sham groups respectively ( $\mathrm{p}<0.001$ and $\mathrm{p}<0.05$ respectively). There was no significant difference between OVX-Est and Sham-Est groups in thiol group (Fig 5). MDA concentration in cortical tissues of ovariectomized animals was higher than sham operated ones $(p<0.05)$. Chronic treatment of both the ovariectomized and sham-operated rats by $4 \mathrm{mg} / \mathrm{kg}$ estradiol increased MDA concentration in cortical tissues in comparison with saline treated Sham and OVX rats $(\mathrm{p}<0.05$ and

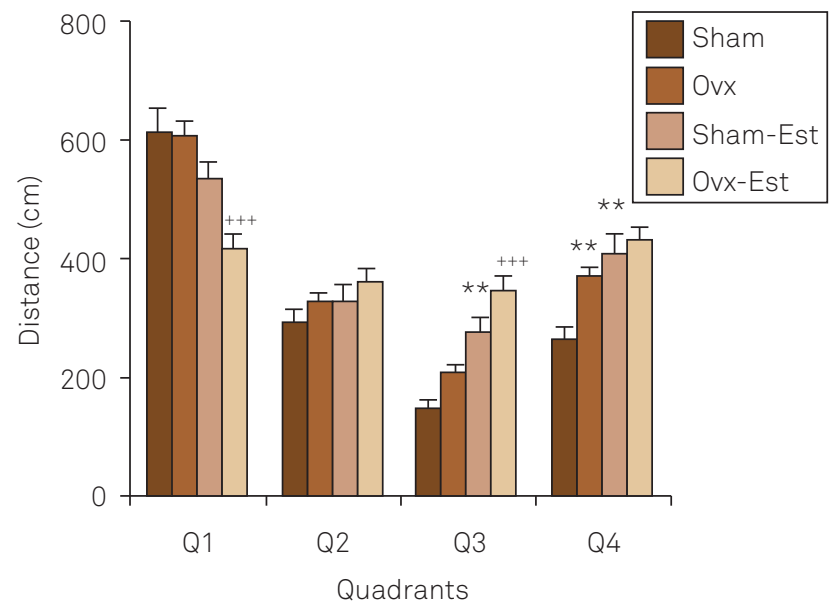

OVX: ovariectomized; Sham-Est: Sham-estradiol; OVX-Est: ovariectomizedestradiol; SEM: standard error median. Data are shown as mean \pm SEM of eight animals per group. The platform was removed, and the length of the swim path in the target quadrant (Q1) and non target quadrants (Q2-Q4) was compared between the groups. ${ }^{*} p<0.01$ compared to Sham group, ${ }^{+++} p<0.001$ compared to OVX group.

Fig 4. The results of the length of the swimming path $(\mathrm{cm})$ in each quadrant during the probe trial on day 6 (24 h after the last secession of learning).

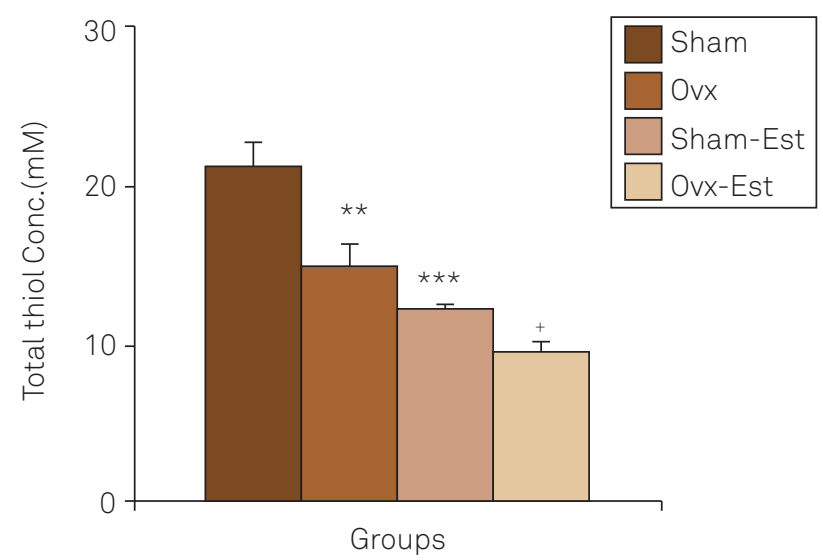

OVX: ovariectomized; Sham-Est: Sham-estradiol; OVX-Est: ovariectomizedestradiol; SEM: standard error median. Data are shown as mean \pm SEM of eight animals per group. ${ }^{* *} p<0.05,{ }^{* *} p<0.001$ compared to Sham group, ${ }^{+} p<0.05$ compared to OVX group.

Fig 5 . The total thiol concentrations in cortical tissues of four groups.

$\mathrm{p}<0.01$ respectively) (Fig 6). The results also showed that the serum $17 \beta$-estradiol concentration in OVX group was significantly higher than that of sham operated rats $(p<0.001)$ (Fig 6). Fig 7 shows treatment by $4 \mathrm{mg} / \mathrm{kg}$ estradiol increased $17 \beta$-estradiol serum concentration in ovariectomized and sham operated animals $(\mathrm{p}<0.001)$.

\section{DISCUSSION}

The results of the present study indicated that OVX rats had more time and path length to reach the platform in comparison with Sham group. The results also showed that 


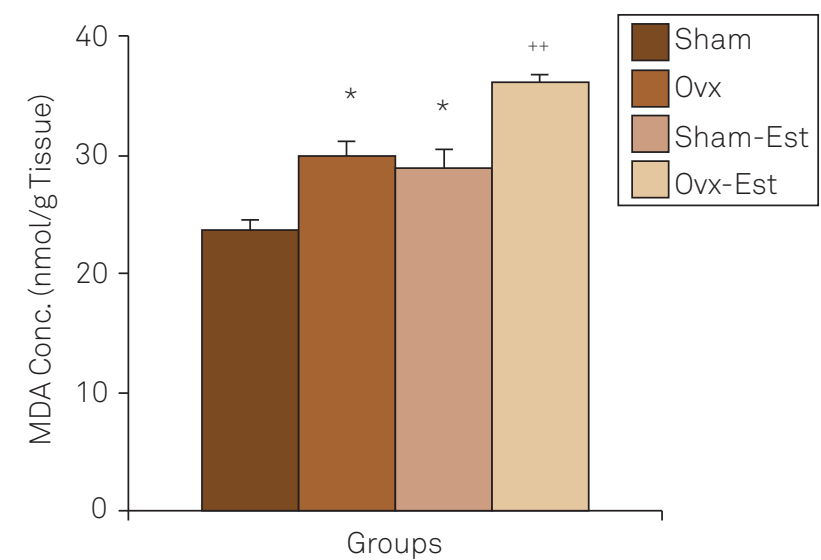

MDA: malondialdehyde; OVX: ovariectomized; Sham-Est: Sham-estradiol; OVX-Est: ovariectomized-estradiol; SEM: standard error median. Data are shown as mean \pm SEM of eight animals per group. ${ }^{\star} p<0.05,{ }^{*} p<0.01$ compared to Sham group, ${ }^{++} p<0.01$ compared to OVX group.

Fig 6. Comparison of MDA concentrations in cortical tissues between four groups.

deprivation of rats from ovarian hormones affects retention phase of Morris water maze in rats. However, there were no significant differences between OVX and Sham-operated rats in the time spent and traveled distance in target quadrant in probe trial when the platform was removed from the tank; the animals of OVX rats spent more time and traveled longer distance in non target quadrant (Q4) in comparison with sham animals. The results of the present study confirmed the results of previous studies showing that ovariectomy impairs spatial memory ${ }^{4}$. However, it was found no effect of surgical menopause on cognitive functioning ${ }^{3}$.

Estrogen replacement therapy has been reported to prevent or delay cognitive decline in postmenopausal women and in estrogen-depleted animals $\mathrm{s}^{3,4}$. It has been suggested that the effect of exogenous administration of estradiol on learning and memory of ovariectomized female rats depends on the dose and the estradiol plasma concentration. Low, but physiological, levels of exogenous estradiol enhances performance whereas administration of high exogenous pharmacological or physiological levels of estradiol impairs performance ${ }^{7}$. The results of our previous study also showed that treatment by $2 \mathrm{mg} / \mathrm{kg}$ estradiol valerate for eight weeks improves Morris water maze tasks of ovariectomized rats, however deleterious effects of estradiol was seen in the same dose and time when administered to Sham-operated rats ${ }^{4}$. It has also been suggested that, during the breeding season (high estradiol), female voles show poor performance in comparison with males in the spatial version of the water escape $\operatorname{task}^{12}$. Besides of the dose of estradiol, the discrepancies of the data may be due to the differences in type of memory which is studied or the age of OVX animals.

Estrogen exerts its memory-related effect via multiple pathways including antioxidant properties, which may also have a role in its neuroprotective effects ${ }^{10}$. The

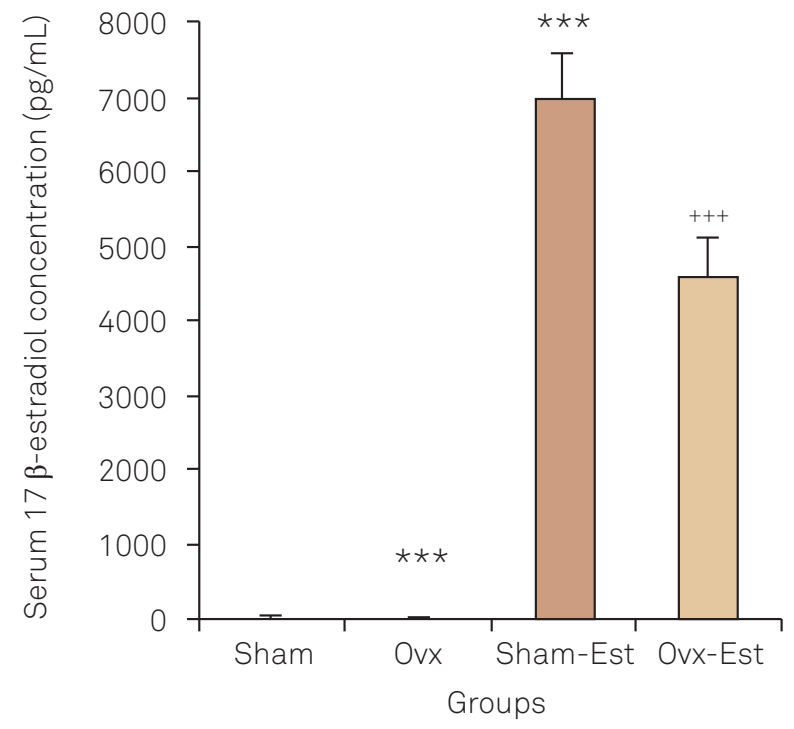

OVX: ovariectomized; Sham-Est: Sham-estradiol; OVX-Est: ovariectomizedestradiol; SEM: standard error median. Data are shown as mean \pm SEM of eight animals per group. ${ }^{*} * \mathrm{p}<0.001$ compared to Sham group, ${ }^{+++} \mathrm{p}<0.01$ compared to OVX group.

Fig 7. Comparison of serum estradiol level between four groups.

antioxidant property of the estradiol has been attributed to its free phenolic hydroxyl group on the A-ring of the steroid. Removal or blocking of the phenolic hydroxyl group eliminates the antioxidant effect, as well the neuroprotection properties ${ }^{10}$. The results of the present experiment demonstrated that $\mathrm{SH}$ contents in cortical tissues were decreased and MDA concentration increased after ovariectomy. Ovariectomy model has been widely used as an in vivo model to mimic post-menopausal pathophysiological changes in women related to learning and memory and brain oxidative stress ${ }^{13}$. Therefore, it is suggested that learning and memory impairments which were seen in ovariectomized rats in comparison to the sham animals at least in part may be due to brain tissues oxidative damage. The cognitive impairments due to human menopausal conditions may also be related to brain oxidative damage. The results of previous studies have also confirmed that ovariectomy of animals or postmenopausal conditions in women increase lipid peroxidation in brain, erythrocytes and plasma ${ }^{13}$.

Neuroprotective effect of estrogen has been attributed to its antioxidant properties of estrogen. It has been shown that the low nanomolar doses of estrogen has neuroprotection effect in rodent models and reduces brain lipid peroxidation ${ }^{14}$. It was also shown that estrogens prevent intracellular peroxide accumulation in an endoplasmic reticulum (ER)-independent manner ${ }^{15}$, decrease reactive oxygen species (ROS) production ${ }^{16}$, limit lipid peroxidation and decrease hydrogen peroxide concentrations ${ }^{17}$. Indirect anti-oxidative effects of estrogens have been reported, including attenuation of microglial superoxide release ${ }^{18}$, 
increase of glutathione reductase, gamma-glutamylcystein synthetase, glutaredoxin and glutathione ${ }^{10}$, increased manganese superoxide dismutase (MnSOD) activity ${ }^{19}$ and reduction of free radical production via an increase mitochondrial efficiency ${ }^{20}$. The ability of estrogens for regeneration of vitamin $\mathrm{E}$ has also been suggested ${ }^{21}$. It has also been shown that estrogens potentiated lipid peroxidation inhibitors $^{22}$. Estrogens are highly lipid soluble and largely reside in the membrane component of cells ${ }^{23}$. In fact, there is evidence that estrogen prevents lipid peroxidation by sacrificing itself to oxidation ${ }^{24}$. This estrogen redox cycle is operative in the brain and serves, together with the classic antioxidant mechanism, as a defense mechanism against ROS.

The results of the present study indicated that administration of a high dose $(4 \mathrm{mg} / \mathrm{kg})$ of exogenous estradiol valerate impaired learning and memory in sham and ovariectomized which was accompanied by low level of total SH groups in cortical tissues.

This result was in contrast with the findings mentioned and showed beneficial effects of estradiol on learning and memory and its antioxidant properties. In consistent with the results of present study, it has been shown that high doses of estradiol have deleterious effects on memory and learning. Varga et al. showed that Sprague-Dawley ovariectomized rats treated by the high dose of estradiol displayed a week performance in the water maze task in comparison with non treated ones ${ }^{25}$. It has also been reported that chronic administration of high doses of estradiol impairs performance on a working/reference memory in the eight-arm radial arm maze $^{7}$. Fugger et al. also showed that treatment of the female, but not male, mice with estradiol impairs acquisition of water maze tasks ${ }^{26}$.

We hypothesized that the negative effects of a high dose of estradiol seen in the present study may be related to its pro-oxidative effects. The results showed that in both Sham-Est and OVX-Est rats the MDA concentrations was higher and total thiol concentration was lower than that of sham and ovariectomized rats. It should be noted that in at least one study, estradiol administration was resulted in a time-dependent increase in lipid peroxidation ${ }^{27}$. It seems that the differential actions of estrogens as a pro-oxidant or an antioxidant depends in part on their metabolism and the subsequent actions of the metabolites ${ }^{28}$. It has been shown that estrogen administration to rodents results in the initiation of tumors in several organs ${ }^{29}$. The induction of renal tumors in Syrian hamsters due to chronic exposure to estrogens is an extensively studied model of carcinogenesis. It has been shown that estrogen-induced free radicals play a tumor-initiating role in this process ${ }^{27,30}$. It was shown that renal lipid peroxide concentrations were raised by chronic treatment with estradiol ${ }^{27}$. It was also shown that certain metabolites of estradiol or estrone can directly produce DNA damage in target tissues, independent of their interaction with the estrogen receptor ${ }^{29}$. The genotoxic effect of hydroxyestrogens has also been related to the generation of free radicals ${ }^{29}$. Indeed, hydroxyestrogen-semiquinone intermediates can react in vitro with molecular oxygen yielding the superoxide anion (O2•-). Finally it seems that estrogens have dual actions in reference to their oxidative effects ${ }^{31}$.

In conclusion, the results of present study show that a high dose of estradiol impairs spatial learning and memory. Our results also indicate that the oxidative stress in brain cortical tissues might take part in spatial learning and memory impairments due to high levels of estradiol, but further investigations using more methods need to be done.

\section{ACKNOWLEDGMENTS}

The results described in this paper were from a M.Sc. student thesis proposal. The authors would like to thank the Vice Chancellor of Research Affairs of Mashhad University of Medical Science for financial assistance.

\section{References}

1. Azizi-Malekabadi H, Hosseini M, Soukhtanloo M, Sadeghian R, Fereidoni M, Khodabandehloo F. Different effects of scopolamine on learning, memory, and nitric oxide metabolite levels in hippocampal tissues of ovariectomized and Sham-operated rats. Arq Neuropsiquiatr 2012;70:447-452.

2. Frick KM. Estrogens and age-related memory decline in rodents: What have we learned and where do we go from here? Horm Behav 2009;55:2-23.

3. Vearncombe KJ, Pachana NA. Is cognitive functioning detrimentally affected after early, induced menopause? Menopause 2009;16:188-198.

4. Hosseini M, Headari R, Oryan S, Hadjzadeh MA, Saffarzadeh F, Khazaei M. The effect of chronic administration of L-arginine on the learning and memory of estradiol-treated ovariectomized rats tested in the morris water maze. Clinics 2010;65:803-807.

5. Chesler EJ, Juraska JM. Acute administration of estrogen and progesterone impairs the acquisition of the spatial morris water maze in ovariectomized rats. Horm Behav 2000;38:234-242.

6. Galea LA, Kavaliers M, Ossenkopp KP, Hampson E. Gonadal hormone levels and spatial learning performance in the Morris water maze in male and female meadow voles, Microtus pennsylvanicus. Horm Behav 1995;29:106-125.

7. Holmes MM, Wide JK, Galea LAM. Low levels of estradiol facilitate, whereas high levels of estradiol impair, working memory performance on the radial arm maze. Behav Neurosc 2002;116:928-934.

8. Galea LAM, Wide JK, Paine TA, Holmes MM, Ormerod BK, Floresco SB. High levels of estradiol disrupt conditioned place preference learning, stimulus response learning and reference memory but have limited effects on working memory. Behav Brain Res 2001;126:115-126. 
9. Frlich L, Riederer P. Free radical mechanisms in dementia of Alzheimer type and the potential for antioxidative treatment. ArzneimittelForschung 1995;45:443-446.

10. Niki E, Nakano M. Estrogens as antioxidants. Meth Enzymol 1990;186:330-333.

11. Vedder H, Anthes N, Stumm G, Würz C, Behl C, Krieg JC. Estrogen hormones reduce lipid peroxidation in cells and tissues of the central nervous system.J Neurochemistry 1999;72:2531-2538.

12. Galea LAM, Kavaliers M, Ossenkopp KP, Hampson E. Gonadal hormone levels and spatial learning performance in the Morris water maze in male and female meadow voles, Microtus pennsylvanicus. Horm Behav 1995;29:106-125.

13. Monteiro SC, Matté C, Bavaresco CS, Netto CA, Wyse ATS. Vitamins E and $\mathrm{C}$ pretreatment prevents ovariectomy-induced memory deficits in water maze. Neurobiol Learn Mem 2005;84:192-199.

14. Green PS, Gridley KE, Simpkins JW. Nuclear estrogen receptorindependent neuroprotection by estratrienes: a novel interaction with glutathione. Neuroscience 1998;84:7-10.

15. Behl C, Skutella T, Lezoualc'h F, et al. Neuroprotection against oxidative stress by estrogens: structure-activity relationship. Mol Pharmacol 1997;51:535-541.

16. Culmsee C, Vedder H, Ravati A, et al. Neuroprotection by estrogens in a mouse model of focal cerebral ischemia and in cultured neurons: evidence for a receptor-independent antioxidative mechanism. J Cerebral Blood Flow Metabolism 1999;19:1263-1269.

17. Kii N, Adachi N, Liu K, Arai T. Acute effects of 17beta-estradiol on oxidative stress in ischemic rat striatum. J Neurosurg Anesthesiol 2005;17:27-32.

18. Bruce-Keller AJ, Keeling JL, Keller JN, Huang FF, Camondola S, Mattson MP. Antiinflammatory effects of estrogen on microglial activation. Endocrinology 2000;141:3646-3656.

19. Gottipati S, Cammarata PR. Mitochondrial superoxide dismutase activation with 17 beta-estradiol-treated human lens epithelial cells. Mol Vis 2008;14:898-905.
20. Nilsen J, Irwin RW, Gallaher TK, Brinton RD. Estradiol in vivo regulation of brain mitochondrial proteome. J Neurosc 2007;27:14069-14077.

21. Mukai K, Daifuku K, Yokoyama S, Nakano M. Stopped-flow investigation of antioxidant activity of estrogens in solution. Biochim Biophys Acta 1990;1035:348-352.

22. Wang X, Simpkins JW, Dykens JA, Cammarata PR. Oxidative damage to human lens epithelial cells in culture: estrogen protection of mitochondrial potential, ATP, and cell viability. Invest Ophthalmol Vis Sci 2003;44:2067-2075

23. Liang Y, Belford S, Tang F, Prokai L, Simpkins JW, Hughes JA. Membrane fluidity effects of estratrienes. Brain Res Bull 2001;54:661-668.

24. Prokai L, Prokai-Tatrai K, Perjesi P, et al. Quinol-based cyclic antioxidant mechanism in estrogen neuroprotection. Proc Nat Acad Sci USA 2003;100:11741-11746.

25. Varga H, Németh H, Tth T, Kis Z, Farkas T, Toldi J. Weak if any effect of estrogen on spatial memory in rats. Acta Biol Szegediensis 2002;46:13-16.

26. Fugger HN, Cunningham SG, Rissman EF, Foster TC. Sex differences in the activational effect of ERalpha on spatial learning. Horm Behav 1998;34:163-170.

27. Wang MY, Liehr JG. Induction by estrogens of lipid peroxidation and lipid peroxide-derived malonaldehyde-DNA adducts in male Syrian hamsters: role of lipid peroxidation in estrogen-induced kidney carcinogenesis. Carcinogenesis 1995;16:1941-1945.

28. Nathan L, Chaudhuri G. Antioxidant and prooxidant actions of estrogens: potential physiological and clinical implications. Semin Reprod Med 1998;16:309-314.

29. Liehr JG. Dual role of oestrogens as hormones and pro-carcinogens: tumour initiation by metabolic activation of oestrogens. Eur $\mathrm{J}$ Cancer Prev 1997;6:3-10

30. Kirkman H. Estrogen-induced tumors of the kidney. III. Growth characteristics in the Syrian hamster. Nat Cancer Inst Monograph 1959;1:1-57.

31. Roy D, Liehr JG. Estrogen, DNA damage and mutations. Mutat Res 1999;424:107-115. 